\title{
Présentation des écrivains
}

\section{Karin Holter}

\section{(2) OpenEdition}

\section{Journals}

Édition électronique

URL : http://journals.openedition.org/ccs/685

DOI : $10.4000 /$ ccs. 685

ISSN : 2558-782X

\section{Éditeur :}

Presses universitaires de Rennes, Association des lecteurs de Claude Simon

\section{Édition imprimée}

Date de publication : 31 décembre 2010

Pagination : 163-166

ISBN : 9782354120771

ISSN : 1774-9425

\section{Référence électronique}

Karin Holter, «Présentation des écrivains », Cahiers Claude Simon [En ligne], 6 | 2010, mis en ligne le 21 septembre 2017, consulté le 15 septembre 2020. URL : http://journals.openedition.org/ccs/685 


\section{Paroles d'écrivains}



Parmi les quatre écrivains norvégiens présentés ici, un seulement, Ole Robert Sunde (né en 1952), a publiéson premier livre au moment où Claude Simon recevait le prix Nobel. Les trois autres sont nés dans les années 1960 - après la publication de La Route des Flandres - et si Rune Christiansen (né en 1963) fait paraître son premier recueil de poèmes en 1986, Anne Oterholm (née en 1964) et Christopher Grondahl (né en 1969) publient leurs premiers romans respectivement en 1995 et 1998. Ce sont donc des écrivains encorejeunes et très actifs sur la scène littéraire norvégienne qui parlent ici de leur rapport à l'œuvre de Claude Simon.

Deux des textes datent de 2005 : une réaction à vif, d'abord, celle d'Anne Oterholm, à la mort de Claude Simon, et l'extrait d'un " hommage à Claude Simon " écrit par Rune Christiansen à la même occasion. Tous les deux m'ont accordé leur autorisation pour que je traduise leurs témoignages et rende ainsi possible leur publication ici. Les deux autres textes, celui d'Ole Robert Sunde et de Christopher Grondahl, ont étéécrits et traduits spécifiquement pour ce numéro des Cahiers Claude Simon.

Anne Oterholm. Après une maîtrise de français et un mémoire sur Marguerite Duras remarquable pour ses qualités littéraires, "Détruire, dit-elle : La voix du texte» (1994), Anne Oterholm a débuté en 1995, avec le roman Ikke noe annet enn du vil (Rien que ce que tu veux). A la dijférence des autres écrivains de ce groupe, elle n'écrit que des romans, sept en tout jusqu'ici, le dernier, Togetfra Ajaccio (Le train venant d'Ajaccio), 2009, tous différents les uns des autres, mais tous marqués par sa voix spécifique. Depuis 2005, Anne Oterholm est présidente de l'Association norvégienne des écrivains. 
Ole Robert Sunde, l'aîné du groupe, est celui qui a été le premier et sans doute aussi le plus directement fasciné et influencé par l'écriture simonienne dans ses premiers romans, Den lange teksten historie (Le long texte-histoire), 1984, et Kontrapunktisk (En contrepoint), 1987. Et ce, defaçon tellement intense qu'il avoue avoir eu besoin de se libérer complètement de cette influence pour pouvoir continuer sa propre recherche d'écrivain. Sunde pratique aussi bien la poésie et l'essai que le roman et, dans ses derniers textes, un mélange de genres où réflexion philosophique, critique littéraire et fiction se côtoient et s'imbriquent.

Rune Christiansen a été poète avant de devenir romancier; neuf recueils de poèmes à cejour, lepremier, Hvor toget forlater havet (Où le train quitte la mer), 1986, et cinq romans qui, eux aussi, portent le sceau d'un poète écrivain. Ilfaut mentionner les deux derniers : Fraværet av musikk (L'Absence de la musique), 2007, et Krysantemum (Chrysanthème), 2009. Très bien informé de ce qui sepasse sur la scène littéraire internationale, Christiansen est aussi rédacteur d'une série de traductions de poésie contemporaine (chez Oktoberforlag) et il a luimême traduit des textes, entre autres, d'Alain Bosquet et d'Edmond Jabès.

Christopher Grondahl est l'écrivain du groupe dont l'ouvre est génériquement la plus diverse. Comme Anne Oterholm, il «sort»du Département de français de l'Université d'Oslo, avec un mémoire de maîtrise qui propose une adaptation cinématographique de La Route des Flandres. En dix ans il a publié trois romans de caractère très different, et plusieurs pièces radiophoniques, dont Risk (Risque), 2003 (Prix Europa pour la meilleure pièce radiophonique européenne). Il est aussi scénariste de plusieurs films et dramaturge. Son premier roman, Den sjette søvn (Le sixième sommeil), 1998, rappelle de manière complexe et originale l'univers simonien; par un recours manifeste à la "citation" de texte de Claude Simon (la description d'une chevauchée nocturne), par la thématique, par la technique d'imbrication et d'association et, surtout, par une certaine qualité de la voix narrative, à lafois vulnérable et rageuse. 